\title{
Indian Surgical Strike: Implications and Response by Pakistan Dr Salma Malik
}

\begin{abstract}
Ever since the election of Narendra Modi as Prime Minister, India has constantly been on a quest for showcasing and exhibiting its larger than life persona and proving to an audience at home and abroad, its aspirations for greater power status. A shrewd approach, timed to perfection, in a world which despite facing the worst of constant military engagement during the Cold War, is once again slipping into hard power projection. As the contemporary world appears to be fast latching on to the trend of hyper-nationalism, promoted by effective political leadership as the expression of ultimate power projection of its respective countries, over-enthusiastic populations are happily and blindly embracing the idea without realising its consequences. The surgical strike strategy used by Modi against Pakistan must be seen as an effective tool for ensuring re-election of the National Democratic Alliance (NDA), but also as an expression of hyper-nationalism. Such disturbing developments raise serious questions about deterrence stability, the future of India-Pakistan relations and changing dynamics of warfare in the region.
\end{abstract}

Keywords: Surgical Strike, Hyper-nationalism, Deterrence Stability, Preemptive Non-Military Attacks, Hybrid Warfare, Grey Zones, Pulwama Attack, Balakot Strikes.

\footnotetext{
* The author is Assistant Professor at the Department of Defence and Strategic Studies, Quaid-i-Azam University, Islamabad, Pakistan. She can be contacted at: salmamalik@qau.edu.pk.

@ 2020 by the Islamabad Policy Research Institute.

IPRI Journal $\boldsymbol{\square X}$ (1): 72-104.

https://doi.org/10.31945/iprij.200104.
} 
Indian Surgical Strike: Implications and Response by Pakistan

\section{Introduction}

I

believe there is a need for one more action (surgical strike).

However, I would not want to disclose how we want to do it.

The Indian Army Chief Bipin Rawat stated this, on the eve of what would mark the second anniversary to India's claims of carrying out a targeted 'surgical strike' against alleged militants and terrorists across the Line of Control (LoC) in Azad Kashmir. ${ }^{1}$ According to India, in a 12-hour long operation conducted on the night of September 28-29, 2016, its special forces successfully targeted multiple camps, thereby neutralising 70-75 alleged militants and terrorists. However, when challenged by Pakistan, New Delhi failed to offer plausible evidence despite tall claims and extensive publicity. The prospect of one nuclear-armed state launching an unprovoked and premeditated precision strike by its regular forces inside the territory of another, provoking a counter-retaliation is one of the most dangerous and reckless actions in nuclear history, if taken at face value. Islamabad's cautious refrain from a kneejerk reaction; seeking credible evidence and issuing a denial rather than undermining its carefully maintained deterrence stability, prevented escalation.

However, the fanciful prospect of successfully executing such an action against Pakistan became a frenetic preoccupation for the Modi administration, as its election term entered its final few months. Statements such as the one made by General Rawat, became a norm, and a popular (electoral) campaign gimmick for Prime Minister Modi and his cotre of politicians and opinion makers, without realising the gravity of such actions. Remaining sensitive to any surprise action from the Indian side, Pakistan's military undertook necessary defensive measures, in order to counter any aggression. In the month of February, in a signature move, 40 Indian Central Police Reserve Force (CPRF) personnel were killed, when their vehicle was attacked by a lone suicide bomber, at Lethpora in the Pulwama District. Considered a false flag operation by many even within

\footnotetext{
1 "Believe in the Need for Another Surgical Strike, Says Army Chief," Economic Times, September 25, 2018, https://economictimes.indiatimes.com/news/defence/believe-inthe-need-for-another-surgical-strike-says-army-chief/articleshow/65944562.cms.
} 


\section{Salma Malik}

India, this attack provided the Modi establishment with the necessary grounds to launch its much-touted and marketed Surgical Strike 2.0 against Pakistan.

Attributing the attack to Jaish-e-Muhammad (JeM), in the wee hours of February 26, the Indian Air Force (IAF) violated Pakistan's airspace across the LoC, and targeted what they claimed as the JeM headquarters in the hill tracks of Balakot (Khyber Pakhtunkhwa Province). According to Indian accounts, 300 people were killed as a result, with craftily engineered news reports also claiming a critically injured Maulana Masood Azhar, ${ }^{2}$ being treated at a military hospital. ${ }^{3}$ However, neither was there any Jaish presence, nor could India through its costly and highly acclaimed Israeliorigin Rafael Spice 2000 smart bombs ${ }^{4}$ manage to cause any human casualty beyond ecological damage. ${ }^{5}$

The day-long euphoria and celebrations staged throughout India were checkmated the following day when responding to Pakistan's retaliatory strikes at carefully selected targets to signal a cautious and measured response, the IAF was snubbed severely. Two of its fighter aircrafts, a MiG-21 Bison and its pride the Russian top line multirole aircraft $S U$-30 were downed by the Pakistan Air Force, and one Indian pilot detained for 48 hours. This reckless act of aggression by India, which it claimed as a pre-emptive non-military strike, ${ }^{6}$ pushed the two neighbours

\footnotetext{
2 Masood Azhar is the founder and leader of Jaish-e-Muhammad.

3 "Masood Azhar Dead? Speculation Rife about Jaish Chief's Whereabouts," Hindustan Times, March 3, 2019, https://www.hindustantimes.com/india-news/where-is-jemchief-masood-azhar-speculation-rife-about-his-whereabouts-since-airstrike/storyasoS9yJloUC4zZXeYchylN.html.

4 According to Encyclopaedia Britannica, Smart Bombs are also referred to as smart missiles, a type of precision-guided munition, that move in response to guidance commands, enabling adjustments to be made to the angle of the bomb's descent or the direction of its fall.

5 Waleed Tariq, "Pakistan Lodges Complaint at UN against India for Eco-Terrorism," Express Tribune, March 15, 2019, https://tribune.com.pk/story/1930176/1-pakistanlodges-complaint-un-india-eco-terrorism/.

6 India's Foreign Secretary Vijay Gokhale described the Balakot air raid as a pre-emptive non-military strike, in which the term 'non-military' has been used to define the target, which is not a military camp or installation, that are the usual targets in a conventional military attack. Nor was it a civilian target, because in the conventional escalatory
} 
Indian Surgical Strike: Implications and Response by Pakistan

to the brink of a nuclear exchange, with unprecedented global consequences.

New Delhi in its newly donned hyper-nationalist persona had earlier carried out such an operation across its border with Myanmar in June 2015, which after initial disclaimer by the latter was mutually owned by both in order to show a united stance against cross-border militants. ${ }^{7}$ However, the notion of a surgical strike is neither new nor New Delhi's ingenious brainchild. Used at different instances against weaker state-actors as well as in Grey Zone Conflicts, ${ }^{8}$ the United States (US) has been exercising this

ladder, a civilian target would be higher than a military target. The Indian government attempted to showcase that a terrorist camp had been hit in response to a terror attack on India and it fell in the category of 'non-military'. What this also meant was that if Pakistan attacked an Indian military target, it would be seen as escalatory and disproportionate. In other words, the notion that Pakistan could respond against the Indian military because its IAF carried out strikes was not the view in New Delhi. Besides, in the Indian estimate, the 'pre-emptive' tag to the description provided signified self-defence. "IAF Air Strike: Why 'Non-Military Target' Wording?" Economics Times, February 27, 2019,

https://economictimes.indiatimes.com/news/defence/why-non-military-targetwording/articleshow/68178036.cms?utm_source=contentofinterest\&utm_medium=text \&utm_campaign=cppst.

7 Shaurya Karanbir Gurung, "Heavy Casualties Reported in Army's Firefight with Naga Insurgents Alongside Myanmar Border,” Economic Times, July 31, 2018, https://economictimes.indiatimes.com/news/defence/indian-army-carries-out-anothersurgical-strike-on-india-myanmar-border/articleshow/60854235.cms; and, Prashanth Parameswaran, “The Truth about India's Militant Strike in Myanmar. New Delhi's Operation is Much Less Novel or Controversial Than Some Have Claimed," Diplomat, June 12, 2015, https://thediplomat.com/2015/06/the-truth-about-indias-militant-strikein-myanmar/.

8 Typically, the term grey zone conflicts is related to hybrid warfare, and commonly refers to political power being employed to achieve national objectives that is much below the level of physical conflict. Conducted in the 'grey zone' of conflict, meaning operations may not clearly cross the threshold of war, and could be employed as part of a broader campaign - including political, criminal and economic activities. And because they feature the ambiguity associated with the grey zone, they are well suited to achieve political outcomes without resorting to traditional conflict. The 'grey' could be due to the ambiguity of international law, actions and attribution, or because the nature of actions undertaken do not justify a response. "What is 'Hybrid Warfare' and What is Meant by the 'Grey Zone'?” Conversation, June 17, 2019, 


\section{Salma Malik}

sub-conventional tactic in the past. Moreover, apparently since the Mumbai terrorist strikes, Washington had been amiable to the idea of precision strikes inside Pakistan to avenge Mumbai as proposed by the Indian leadership and conveyed in letter to Islamabad by a high-profile US diplomatic mission. ${ }^{9}$

In the following paragraphs, an attempt will be made to examine the rationale and motivation behind India's changing military posture, how long can New Delhi use surgical strike as a viable tactical option and how it affects deterrence stability between the two countries? Has New Delhi realised the implications of such an action after the Balakot attack? What implications does this hold for Pakistan; and lastly, how Islamabad has and will deal with the changing dynamics of conflict in the region?

\section{Surgical Strikes - Transformation in Military Strategy}

According to Schultz and Pfaltzgraff, surgical strike can be defined as a swift and targeted military attack intended to damage only a legitimate military target, with no or minimal collateral damage to surrounding structures, vehicles, buildings, or the general public infrastructure and utilities. ${ }^{10}$ Previously christened as precision bombing, neither is this a new tactic, nor unprecedented, being introduced in World War I, when the Allied and Central powers unsuccessfully attempted precision attacks through air power was used as a viable military strategy. This failure in precision was primarily due to lack of advanced technology, which has in the past century improved extensively due to guided munitions, smart technology and stand-alone weapon systems, with increased accuracy and lethality.

Though originally referred to German armour and mechanised attacks against France and other countries in World War II, in contemporary conflict lexicon the notion of such Blitzkrieg strikes is commonly associated with air power, whether through guided missiles, unmanned aerial vehicles

http://theconversation.com/explainer-what-is-hybrid-warfare-and-what-is-meant-bythe-grey-zone-118841.

9 Khurshid Mahmud Kasuri, Neither a Hawk nor a Dove: An Insider's Account of Pakistan's Foreign Relations (Karachi: Oxford University Press, 2015), 433-435.

10 Richard H. Shultz, Jr. and Robert L. Pfaltzgraff, Jr., eds., The Future of Air Power: In the Aftermath of the Gulf War (Darby, PA: Diane Publishing, 1992). 
or precision air strikes. However, countries such as Israel as well as the US have frequently used this strategy with ground forces to derive maximum effect through minimal effort involving meticulous and targeted operations. The 1976 Operation Thunderbolt conducted in Uganda by Israeli commandos to release hostages from hijackers of Tel Aviv bound Air France flight being one such strike. ${ }^{11}$ The US has repeatedly used this tactic in its long wars in Afghanistan, Iraq as well as during peace time, when targeting al-Qaeda leadership in Yemen, Sudan or Somalia — indicative of a change in military strategy. As stated by John Brennan, former US President Barack Obama's Counter Terrorism Advisor:

Going forward, we will be mindful that if our nation is threatened, our best offense won't always be deploying large armies abroad but delivering targeted, surgical pressure to the groups that threaten us. ${ }^{12}$

This controversial and conflicting transformation in military strategy was institutionalised and deemed highly effective by the US administration, especially under Barack Obama, who in May 2013, announced new policy guidance for US targeted killings on the conventional battlefield, in order 'to determine how we can continue to fight terrorists without keeping America on a perpetual war-time footing. ${ }^{13}$ Although its increased military adventurism since $9 / 11$ and reluctant yet definite reflexing of military muscle (Somalia, Kosovo) even prior to the global War on Terror

11 Saul David, Operation Thunderbolt: Flight 139 and the Raid on Entebbe Airport, Reprint Edition (New York: Back Bay Books, 2017); and, “'Operation Thunderbolt”: The Mission that Catapulted Benjamin Netanyahu's Political Career," Financial Express, January 19, 2018, https://www.financialexpress.com/world-news/operationthunderbolt-the-mission-that-catapulted-benjamin-netanyahus-politicalcareer/1022024/.

12 John O. Brennan, "Obama Administration Counterterrorism Strategy” (speech, Washington, D.C., June 29, 2011), C-Span, https://www.c-span.org/video/?3002661/obama-administration-counterterror.

13 Barack Obama, "Remarks by the President at the National Defense University," (speech, Washington, D.C., May 23, 2013), White House, https://obamawhitehouse.archives.gov/the-press-office/2013/05/23/remarks-presidentnational-defense-university. 


\section{Salma Malik}

contradicts its post-Nam strategy of military dissociation and use of strategic proxies. The US still remains traumatised by the Vietnam experience, and exercises caution when it comes to long-term presence of boots on ground.

What make such strategies of targeted, precision or surgical strikes dangerous and controversial are what Masters ${ }^{14}$ and Alston ${ }^{15}$ term as a balancing act between opposing imperatives. Exercising broad military powers, while assuring the global audience that they are limited in dimension. Projecting a moralistic stance and justifying wilful violation of other states' sovereignty as being 'well within its rights' to use force without consent under the cover of overriding necessity of self-defence, while objecting to the same by others. Such acts have posed grave danger to international legal frameworks designed to protect the right to life. Such killings - defined as the intentional, premeditated, and deliberate use of lethal force, by a state or its agents acting under colour of law, against a specific individual who is not in the perpetrator's custody - is permitted only in exceptional circumstances, and international law requires that any state that uses targeted killing must demonstrate that its actions comply with the laws of war. ${ }^{16}$ However, by this deliberate disregard of international law and norms, the US has encouraged a trend for its select group of allies, foremost amongst them Israel, and now India, to mimic such strategies that would result in chaos and dangerous conflict escalation, all in the name of precise and minimally invasive targeted strikes. New Delhi, on a perpetual quest to emulate the US in order to behave like a great power, has readily incorporated and adopted the strategy in its defence doctrine.

\footnotetext{
14 Jonathan Masters, “Targeted Killings,” Council on Foreign Relations, May 23, 2013, https://www.cfr.org/backgrounder/targeted-killings.

15 "Statement of U.N. Special Rapporteur on U.S. Targeted Killings Without Due Process," American Civil Liberties Union, accessed June 19, 2019, https://www.aclu.org/statement-un-special-rapporteur-us-targeted-killings-without-dueprocess?redirect=national-security/statement-un-special-rapporteur-us-targeted-killingswithout-due-process.

${ }^{16}$ Masters, "Targeted Killings." 
Indian Surgical Strike: Implications and Response by Pakistan

\section{Modi's Mind-set and Military Posturing}

There is no dispute with regards to a country's desire and quest to improve and grow. However, in a highly interdependent world, naked power projection and pursuit, backed by aggressive and threatening posturing and statements aimed at damaging the other can be disastrous for universal peace and security. It appears worse, especially in an equation such as India and Pakistan, two Nuclear Weapons States (NWS) located next to each other in a region that hosts one-fourth of the world's population. India and Pakistan, have in the past, maintained a carefully balanced deterrence regime despite the worse of relations and many crises. However, with Modi's ascent to power, the NDA government has gone into overdrive to project India as a significant global actor, very craftily manipulating global dynamics and sentiment in its favour, and that too, at the cost of regional peace and stability. Between the September 2016 phantom surgical strike across the LoC to the February 2019 Balakot attack, several objectives were served and few backfired as well.

By making the necessary noise about it, India managed to garner attention of the international audience, and characteristically 'created' a bad image of Pakistan. However, the primary target audience was domestic. This backfired when Pakistan denied occurrence of the 2016 strikes and sought credible evidence neither of which India could provide, thereby, denuding claims of any credibility. ${ }^{17}$ Similarly, in the 2019 strike, the alleged hype about hitting its target, claiming a high casualty count and projecting India under Modi as invincible, suffered a severe dent. Pakistan gave a befitting response, and even international watch bodies refuted New Delhi's claims and provided evidence to the contrary. ${ }^{18}$ Furthermore, the rapidly shrinking Indian secular and pacifist civil society, along with a

\footnotetext{
${ }^{17}$ M. Ilyas Khan, “India's 'Surgical Strikes' in Kashmir: Truth or Illusion?” BBC.com, October 23, 2016, https://www.bbc.com/news/world-asia-india-37702790; and, Shawn Snow, "Is India Capable of a Surgical Strike in Pakistan Controlled Kashmir?" Diplomat, September 30, 2016, https://thediplomat.com/2016/09/is-india-capable-of-asurgical-strike-in-pakistan-controlled-kashmir/.

${ }^{18}$ Marcus Hellyer, Nathan Ruser and Aakriti Bachhawat, India's Strike on Balakot: A Very Precise Miss? report (Canberra: Australian Strategic Policy Institute, 2019), https://www.aspistrategist.org.au/indias-strike-on-balakot-a-very-precise-miss/.
} 


\section{Salma Malik}

handful of politicians, condemned this action as reckless election gimmickry.

Since 2014, when Modi became Prime Minister, a new era in Indian foreign and defence policy began. Long gone is even the pretence of notions of Ahimsa, ${ }^{19}$ mutual and peaceful co-existence and non-intervention or noninterference. ${ }^{20}$ Ideals, which even when pronounced by the Indian founding fathers were never followed to the letter.

India has played its cards very well, whether it's the 1962 SinoIndian war, instigating Mukti Bahini militia in East Pakistan during the 1971 Indo-Pakistan war, or using India-backed Tamil militants against the Sinhala government in Sri Lanka, ${ }^{21}$ to engineer the entire Tamil insurgency according to its whims during the 1980s, New Delhi's message to its smaller neighbours, that it is the regional hegemon has been clear.

Whether openly declared in the realist narrative of the Indira Doctrine $^{22}$ or cloaked benignly through the Gujral Doctrine, ${ }^{23}$ the message

${ }^{19}$ Gandhian philosophy of non-violent and peaceful resistance.

${ }^{20}$ Basic tenets of Nehruvian foreign policy, which were included in the five-pronged Panchsheel agreement signed between India and China on April 28, 1954. These comprised of: Mutual respect for territorial integrity and sovereignty; Non-aggression against each other; Non-interference in each other's internal affairs; Equality and mutual benefit; and Peaceful co-existence.

${ }^{21}$ Shenali D. Waduge, "India Gave Birth to LTTE \& Tamil Militancy in Sri Lanka," SinhalaNet, April 7, 2016, http://www.sinhalanet.net/india-gave-birth-to-ltte-tamilmilitancy-in-sri-lanka; and, Akshaya Mishra, "Indira Gandhi Helped Train Tamil Rebels, and Reaped Whirlwind," FirstPost, May 23, 2011, https://www.firstpost.com/world/indira-gandhi-helped-train-tamil-rebels-and-reapedwhirlwind-13913.html.

22 'A set of policy principles authored by Indira Gandhi. It centres on dissuading the influence of external countries within South Asia that have either implicit or explicit anti-Indian agendas, primarily via the deployment of India's military forces as both a deterrent and an interventionist foreign-policy tool. The doctrine typified India's approach to South Asia in the 1970s and 1980s, including the Indian Peacekeeping Mission to Sri Lanka in the 1980s.' A Dictionary of Politics and International Relations in India, s.v. "Indira Doctrine"; and M.B.I. Munshi, The India Doctrine (1947-2007): A Contemporary Study on Indian Hegemony and Geo-Strategic Perspectives on South Asia (Saarbrucken: Lambert Academic Publishing, 2012).

${ }^{23}$ Ibid. '[B]ased on five points, ... the "Gujral Doctrine", if I may call it so, states that, first, with its neighbours like Bangladesh, Bhutan, Maldives, Nepal and Sri Lanka, 
has been the same that India's hegemony and total control over the entire region must willingly and without any question be accepted by its South Asian neighbours. A notion, which to India's irritation, has always been dismissed by Pakistan in comparison to the other regional states, who can never contest New Delhi's military muscle.

What has been a great asset to India is its geostrategic location. Postindependence, heir of the British colonial jewel in the crown ${ }^{24}$ used its position, the prevalent geostrategic dynamics whether during the Cold War or after and its sharp handling of the political sentiment, very aptly. Additionally, India has always been very savvy when it comes to imagebuilding and perception management. One of Narendra Modi's strongest assets, in this age of high-paced visuals and media blitz, was packaging the Greater India mantra to the fullest. The BJP's election manifesto of 2014 titled Ek Bharat Shreshtha Bharat, ${ }^{25}$ which on the one hand sought inclusivity and respect for common heritage, but by the 2019 elections, the realities on ground had radically changed. Ghar Wapsi ${ }^{26}$ (meaning reconversion to Hinduism) program, cow vigilante violence, ${ }^{27}$ mob

India does not ask for reciprocity, but gives and accommodates what it can in good faith and trust. Second, we believe that no South Asian country should allow its territory to be used against the interests of another country of the region. Third, that none should interfere in the internal affairs of another. Fourth, all South Asian countries must respect each other's territorial integrity and sovereignty. And finally, they should settle all their disputes through peaceful bilateral negotiations.' I.K. Gujral "Aspects of India's Foreign Policy,” (speech, Sri Lanka, January 20, 1997), Stimson Center, https://www.stimson.org/1997/the-gujral-doctrine/.

${ }^{24} \mathrm{~A}$ term used in classic fiction to refer to sub-continental India under Colonial Britain.

${ }^{25}$ Literal translation of the term is One Bharat, Greater Bharat, where the term Bharat is retraced from the oldest Hindu ancient texts of Ramayan and Mahabharata (200 BC to 300 AD). "Why Does India Have Three Names: India, Bharat and Hindustan?" Quora.com, https://www.quora.com/Why-does-India-have-three-names-India-Bharatand-Hindustan.

${ }^{26}$ Arshad Afzal Khan, "VHP to Hold 'Ghar Wapsi' for 4,000 Muslims in Ayodhya in January," Times of India, December 24, 2014, https://timesofindia.indiatimes.com/india/VHP-to-hold-ghar-wapsi-for-4000-Muslimsin-Ayodhya-in-January/articleshow/45624372.cms.

27 Tommy Wilkes and Roli Srivastava, "Protests Held across India after Attacks against Muslims," Reuters, June 28, 2017, https://in.reuters.com/article/india-protests/protestsheld-across-india-after-attacks-against-muslims-idINKBN19J2C3. 


\section{Salma Malik}

lynching, affirming the construction of Ram Mandir in place of the historic Babri Masjid, and efforts at revoking constitutional Article 370, that accorded the Indian occupied territories of Jammu \& Kashmir a special status, not only intimidated but also alienated the Muslim population.

India's Muslims, who make up some 14 per cent of the population, have been subjected to episode after violent episode, in which Hindu mobs, often with what seems to be the state's tacit support, have carried out a series of public lynchings in the name of the holy cow, that ready symbol of Hindu piety. ... The response of leadership in every instance is the same: virtual silence. Basic norms and civility have been so completely vitiated that Modi can no longer control the direction of the violence. ${ }^{28}$

Modi's re-election and BJP's resounding success in 2019 elections has been due to several factors. Firstly the dissatisfactory performance by the Congress Party; consolidation of the Hindu vote complimented by a geographically dispersed Muslim vote bank; and lastly, Muslims despite constituting 14 per cent of the over one billion population and their vote bank, for BJP was only 8 per cent of the total tally, thus, making it irrelevant. ${ }^{29}$ Compounded further by the irredentist statements and claims by BJP-RSS leadership, such as, 'The RSS still believes that one day [India, Pakistan and Bangladesh], which have for historical reasons separated only 60 years ago, will again, through popular goodwill, come together and Akhand Bharat will be created. ${ }^{30}$ Echoing similar thoughts, RSS leader

${ }^{28}$ Aatish Taseer, "Can the World's Largest Democracy Endure Another Five Years of a Modi Government?" Time, May 9, 2019, https://time.com/5586415/india-electionnarendra-modi-2019/.

${ }^{29}$ Kaushik Deka, "Verdict 2019: The End of the Muslim Vote Bank?" India Today, May 27, 2019, https://www.indiatoday.in/india-today-insight/story/lok-sabha-electionmuslim-votebank-bjp-congress-1535453-2019-05-27.

30 "One day, India, Pak and Bangladesh Could Reunite as Akhand Bharat: Ram Madhav," Indian Express, December 27, 2015, https://indianexpress.com/article/india/india-newsindia/rss-belives-india-pak-and-bangladesh-will-reunite-through-goodwill-one-dayram-madhav/. 
Indresh Kumar claimed that, 'Pakistan would reunite with India by 2025 , that Indians would settle in and migrate to Lahore.... and a European Unionstyle Akhand Bharat would form. ${ }^{31}$ Thus, crafting an image of Bharat which would be Shreshtha and Akhund by all accounts.

This hybrid warfare ${ }^{32}$ appealed to the domestic audience, of which a more significant percentage comprised of first time voting youth, who were quite dissatisfied with the previous coalition government's lack of performance. The promise of Vikas - development ${ }^{33}$ had them all cheering and campaigning for the promised Messiah. At the economic front, it appealed to foreign investors, who backed by their respective countries, saw a huge economic market in post-reform India, particularly in the age of acute global economic depression. Lastly, his biggest support group and promoters continue to be the saffron lobby which has strived for decades, fighting a Dharamyudya (just war) at the Kurukshetra (battleground) of today to achieve their moment of reckoning - a Hindutva ${ }^{34}$ Bharat. Never the one to miss out on an opportunity to stand with the gods, Modi's battles have been wisely and selectively chosen.

31 "Pakistan to Be Merged with India after 2025: RSS leader Indresh Kumar," India Today, March 17, 2019, https://www.indiatoday.in/india/story/pakistan-to-be-mergedwith-india-after-2025-rss-leader-indresh-kumar-1479998-2019-03-17.

32 According to Bachmann, 'hybrid warfare as a concept emerged shortly after the end of the Cold War and sums up the complexities of modern warfare, which go beyond conventional military tactics, often involving cyberwarfare, propaganda and a fluid, non-state adversary. It has the potential to transform the strategic calculations of potential belligerents [because it has become] increasingly sophisticated and deadly.' It builds on existing doctrinal elements and adds evolving war-fighting capacities in the fifth dimension such as 'cyber-warfare'; and information sphere. Sascha Dov Bachmann, interview by the Remote Control project, Oxford Research Group, November 4, 2016, https://www.oxfordresearchgroup.org.uk/blog/interview-saschadov-bachmann?

${ }^{33}$ Vikas is a term in Hindi for economic and social development and uplift.

34 'Hindutva is a territorial and racial conception of Hinduism and a form of fundamentalism... justifying a new definition of 'Hindu' that has to do with an experience of Hindu-ness. Wendy Doniger, "The Fight for the History of Hinduism in the Academy," in Pluralism and Democracy in India: Debating the Hindu Right, eds., Wendy Doniger and Martha C. Nussbaum (New York: Oxford University Press, 2015), 310 . 


\section{Salma Malik}

During the 2014 general elections in India, the shenanigans of the other neighbour or the evil twin (Pakistan) became a constant mantra for Modi - himself a hardliner, to appease the ultra-nationalist lobby. By the 2019 elections, this hate-mongering had become a viable and perpetual election strategy to stir public sentiments and divert their attention from promises undelivered. ${ }^{35}$ The constant anti-Pakistan bashing, which on the one hand has made minority groups, primarily Muslims fear for their future, it has set India on a path of intolerance and discrimination that has started to severely erode the social fabric of the state. The passage of discriminatory amendments and implementation of the National Register of Citizens (NRC) ${ }^{36}$ in August 2019 and the anti-Muslim specific Citizenship Amendment Act $(\mathrm{CAA})^{37}$ in December 2019 have been met with extreme consternation and violent protests of which the deadly anti-Muslim riots in Delhi ${ }^{38}$ are a stark manifestation.

However, by portraying to be the only saviour of the country, beleaguered by Pakistan, and now its Chowkidar ${ }^{39}$ Modi was successful in building a hyper-nationalist image for himself and India. As mentioned earlier, it is not only India, which is facing a wave of acute self-

\footnotetext{
${ }^{35}$ Kumar Shakti Shekhar, "After 4 Years, Here are the Promises Modi Govt Could Not Keep,” India Today, May 26, 2018, https://www.indiatoday.in/4-years-of-modigovernment/story/after-4-years-here-are-the-promises-modi-govt-could-not-keep1242120-2018-05-26.

36 "NRC Final List: How and Where to Check Your Name on Assam's National Register of Citizens," India Today, August 31, 2019, https://www.indiatoday.in/india/story/nrcfinal-list-how-and-where-to-check-your-name-on-assam-national-register-of-citizens1593695-2019-08-31.

${ }^{37}$ Press Information Bureau, Government of India, "Parliament Passes the Citizenship (Amendment) Bill 2019," press release, December 21, 2019, https://pib.gov.in/PressReleasePage.aspx?PRID=1596059.

${ }^{38}$ Sameer Yasir and Billy Perrigo, “'Hate Is Being Preached Openly against Us’ After Delhi Riots, Muslims in India Fear What's Next," Time, March 3, 2020, https://time.com/5794354/delhi-riots-muslims-india/; and, Soumya Shankar, "India's Citizenship Law, in Tandem with National Registry, Could Make BJP's Discriminatory Targeting of Muslims Easier," Intercept, January 30, 2020, https://theintercept.com/2020/01/30/india-citizenship-act-caa-nrc-assam/.

39 Dhiramohan Ray, “Make Me Nation's Chowkidar, says Modi," Pioneer, April 12, 2014, https://www.dailypioneer.com/2014/state-editions/make-me-nations-chowkidar-saysmodi.html.
} 
actualisation. Representative democracies, such as the USA under Donald Trump, France, United Kingdom and many others have won widespread support and maximised their power through this self-serving narrative. This, in the long run, is taking the world towards an intolerant, authoritarian system, where hardcore power is going to be the meta-narrative.

In the case of India, it is the anti-Pakistan narrative which Modi has expertly drawn to rely on public sentiment, exploit military support and present a victim image worldwide. Indeed a perilous and narrow selfserving approach, but it has been effective in the current geopolitical milieu. The phantom 2016 surgical strike in Azad Kashmir and the 2019 Balakot attack accompanied by fiery statements regarding the need for more by then Indian military chief Bipin Rawat and Prime Minister Modi are also a part of appealing to concerned lobbies. Gokhale observes that it was primarily 'a tactical strike with strategic implications. ${ }^{40}$ First, it helped in actualising Modi's election rhetoric and made him look credible in the eyes of various domestic actors including the military. Projecting himself as the true patriot and the sole saviour, in a September 2013 election rally Modi stated: 'the problem lies in Delhi, not at the borders. Only a competent, patriotic and people-oriented government at the centre can solve the problem. ${ }^{41}$

His transit stop at Lahore to the then-Pakistani Prime Minister's private residence on the eve of December 25, 2015 in order to facilitate trade passage for India's industrialist lobby, followed by attacks by indigenous Kashmir fighters on Pathankot (2015) and Uri (2016) exposed him to criticism. For a person who nurtures a god-complex and considers his transformation in the eyes of the masses from man to god, as a divine calling ${ }^{42}$ - breaking the shackles by doing the unthinkable $e^{43}$ was expected:

40 Nitin A. Gokhale, Securing India the Modi Way: Pathankot, Surgical Strikes and More (New Delhi: Bloomsbury Publishing, 2017), 32.

${ }^{41}$ Ibid.

42 Jehangir S. Pocha, "The God of Small Things: Modi's Divine Mission," Huffington Post, May 22, 2014, https://www.huffingtonpost.com/jehangir-s-pocha/modi-indiagod_b_5374040.html.

${ }^{43}$ Gokhale, Securing India the Modi Way, 2. 
Salma Malik

Modi's supporters divine him as a messianic deliverer who will fix India's problems. His authoritarian style there irked many. ... Others fear Modi will be a violent, vengeful god. The BJP's convoluted 'Hindutva' ideology, a curious and contradictory mix of cultural revivalism, economic Darwinism and militant nationalism, has always been rooted in anger. Much of it has been directed against India's liberals, leftists, Dalits (as 'untouchables' now call themselves) and the Muslim, Christian and other minority communities. The BJP's view is that they have milked the system and public sympathy for undue benefits, which the Congress and other parties have showered on them for electoral and not national benefit. ${ }^{44}$

These incidents provided Modi with the 'necessary pretext' to stage the farcical 2016 'surgical strike' in Azad Kashmir. Thereby, announcing to the world that the risk-taking Modi, who believes in the technique of shock and awe and operates beyond the predictable, had undoubtedly arrived. Last but not least, has been Modi's insatiable paranoia about Pakistan, and the desire of the NDA government to isolate it. As he had stated during an election campaign that India's response to any Pakistani provocation would be a bomb and not chicken biryani. ${ }^{45}$

\section{From Phantom to Real: Surgical Strikes - Viable Tactic for India}

Soon after New Delhi launched a surgical strike across the Myanmar border in June 2015, Rajyavardhan Rathore India's Minister of State for Information and Broadcasting in an interview to the Indian print media stated:

\footnotetext{
${ }^{44}$ Pocha, "The God of Small Things."

45 Bharat Karnad, Staggering Forward: Narendra Modi and India's Global Ambition (New Delhi: Penguin Random House, 2018), 227-228.
} 
We will not tolerate any strikes on India or Indians. We will strike at a place and at a time of our choosing, this is a message for all countries, including Pakistan, and groups harboring terror intent towards India. A terrorist is a terrorist and has no other identity. We will strike when we want to. ${ }^{46}$

Despite questions raised about the credibility of the Myanmar strikes, the operation set the ball rolling for India to court a proactive military posture openly. It further provides India with a template to make similar strikes elsewhere and opening up space between defensive and an all-out conventional response below the nuclear threshold. The notion of exercising surgical strike as a part of full spectrum response and formal military option was incorporated in the 2017 Joint Doctrine Indian Armed Forces, which states:

India has moved to a pro-active and pragmatic philosophy to counter various conflict situations. The response to terror provocations could be in the form of 'surgical strikes', and these would be subsumed in the subconventional portion of the spectrum of armed conflict. The possibility of sub-conventional escalating to a conventional level would be dependent on multiple influences, principally: politically-determined conflict aims; strategic conjuncture; operational circumstance; international pressures and military readiness. Conflict will be determined or prevented through a process of credible deterrence, coercive diplomacy and conclusively

46 Gayeti Singh, "Five Questions That the Myanmar Operation Raises, India's Operation in Myanmar Raises Some Crucial Questions," Citizen, June 11, 2015, https://www.thecitizen.in/index.php/en/NewsDetail/index/1/3979/Five-Questions-ThatThe-Myanmar-Operation-Raises. 


\section{Salma Malik}

by punitive destruction, disruption and constraint in a nuclear environment across the Spectrum of Conflict. ${ }^{47}$

Without regarding the inherent danger in destabilising deterrence stability, for Modi and his government, this new fascination is a feather in their political cap. According to Prakash Menon, for the domestic audience, already euphoric over rising India, the idea of a surgical strike has been projected as symbolic of a government that would not hesitate to take action in the interest of the nation. ${ }^{48}$ Becoming a part of the national political lexicon, 'surgical strike, after that figured in all the elections held at the state levels and was touted as a major achievement of the government. ${ }^{49}$ Therefore, it was no wonder that as the Modi government entered the election year, not only was there increased violence in Indian Occupied Jammu \& Kashmir (IOJ\&K), as well as cross-border firing incidents across the LoC. New Delhi, through its media blitz, showcased alleged Pakistani atrocities, in order to construct an excuse for staging yet another strike. Initially, considered as mere election rhetoric, repeated statements by the Indian Army Chief and the Prime Minister himself, followed by accusations and then the Pulwama attack by a 22-year old Kashmiri youth Adil Ahmed Dar, were well sequenced to justify India's Balakot attack.

Prior to the Pulwama incident, Prime Minister Modi at a ceremony to officially commemorate the 2016 surgical strike's second anniversary openly avowed the need for another round of strikes:

It has been decided that our soldiers will give a befitting reply to whosoever attempts to destroy the atmosphere of peace and progress in our nation. ${ }^{50}$

\footnotetext{
${ }^{47}$ Ministry of Defence, "Spectrum of Conflict," Joint Doctrine, Indian Armed Forces (New Delhi: Headquarters Integrated Defence Staff, Government of India), 2017.

${ }^{48}$ Prakash Menon, The Strategy Trap: India and Pakistan under the Nuclear Shadow (New Delhi: Wisdom Tree, 2018), 146.

${ }^{49}$ Ibid.

${ }^{50}$ Narendra Modi, "Mann Ki Baat” (speech, New Delhi, July 29, 2018), Times of India, https://timesofindia.indiatimes.com/videos/news/full-speech-pm-narendra-modis-mannki-baat/videoshow/65186039.cms.
} 
To a public hungry for action against fellow NWS, Pakistan, this mantra of 'surgical strike' was food for revenge, without realising the repercussions. However, mainstream Indian strategic analysts, as well as the international media, remained sceptical about the veracity of New Delhi's claims. Besides questions with regards the viability of such a tactic was raised. The US-based publication The Diplomat termed the strikes socalled. ${ }^{51}$ Whereas hardliner security analyst, Bharat Karnad dismissed their effectiveness as 'short-term payoffs from such theatrical belligerence, ${ }^{52}$ that will be of little gain to India. In his characteristic disdain for Pakistan, where on the one hand he arrogantly dismissed, 'Pakistan's hollow threat of first use,' he acknowledged that this strategy is, 'stocked by Pakistan's carefully cultivated image as an unpredictable and volatile state. In reality, though, the Deep State represented by the Pakistan Army has been remarkably cautious, rational and pragmatic in judging Delhi's tolerance threshold and never crossing it. ${ }^{53}$ Karnad, furthermore, dismissed the effectiveness of India's Cold Start Doctrine (CSD), a cornerstone of the full spectrum military strategy as a wasteful exercise with limited potential to leverage a bargain from Pakistan. ${ }^{54} \mathrm{He}$ also criticised Modi's fixation on Pakistan in particular, along with past regimes stating that:

India's besetting foreign policy fault, which is also the country's highest military weakness, post-Nehru, is that bereft of a significant and formally articulated national vision, it wallows in the shallows, its once grand design as the geographically pivotal power ...shrivelled to perceiving Pakistan as principle adversary.

\footnotetext{
${ }^{51}$ Ankit Panda, “India's 2017 Joint Armed Forces Doctrine: First Takeaways. India's Latest Joint Military Doctrinal Document Offers New Insight," Diplomat, April 28, 2017, https://thediplomat.com/2017/04/indias-2017-joint-armed-forces-doctrine-firsttakeaways/.

${ }^{52}$ Karnad, Staggering Forward, 227-228.

${ }^{53}$ Ibid., 330 .

54 Ibid., 225-226.
} 


\section{Salma Malik}

Karnad, neither a peacenik nor holds favourable opinion about Islamabad, effectively canvassed a comprehensive approach to either rub the small, weak country [Pakistan] with a tenth of its [India's] GDP, off the face of the earth or corner them through victor's bargain, ${ }^{55}$ instead of employing cost-intensive, poorly strategised policies. The notion of surgical strike despite becoming an essential part of India's full spectrum grand strategy, according to Karnad, thus remained questionable. From the perspective of deterrence, it presented an ambiguous image, where on the one hand, Pakistan denied that such a strike had happened. On the other hand, after creating all the necessary sound-bites about it, the Indian government failed to provide any proof of the (2016) strike.

As stated earlier, the stratagem of surgical strikes may be new to the South Asian theatre, but has been used by the US and Israel to achieve their targets at different intervals, with complete disregard of international law and breaching the norms of state sovereignty. In the South Asian strategic discourse, it was introduced for the first time after the Mumbai incident. According to Khurshid Kasuri, Pakistan's Foreign Minister during the Musharraf regime, a high-level American delegation playing a mediatory role post-Mumbai, approached him with India's wish list. Comprising of Senators John McCain, Lindsey Graham, and US Special Representative for Afghanistan and Pakistan, Richard Holbrooke, the delegation on its return from New Delhi conveyed the latter's anger and sought some means to release the pressure:

What the reaction of the Pakistan Army and the public at large would be, if there was a limited air raid on Muridke, the headquarters of the Lashkar-e-Taiba and its political wing, Jamaat-ud-Dawaah (JUD). The Indians strongly believed that the JUD on orders of Lashkar-e-Taiba's leader Hafiz Saeed was responsible for the Mumbai atrocities. I was sure beyond doubt that the response of the Pakistan Army would be immediate, though measured and commensurate to the raid at Muridke. I do not doubt in my mind that such a suggestion could not have come

\footnotetext{
${ }^{55}$ Karnad, Staggering Forward, 225-226.
} 
without their sounding out people at the highest level in India before their visit to Pakistan. I further told them that they needed to be sensitive to the history of South Asia, and in many instances, it is the gut reaction, which determines how people act in a given situation. ${ }^{56}$

The idea of such an action was dropped thereafter, and at many times since, whenever India even rhetorically brought the issue up, there has been a strong rebuttal from the Pakistani civil-military leadership. However, India managed to furnish a reason and garner international opinion in its favour through the Pulwama attack, and waged an aerial strike inside Pakistan's territory. Whether or not, the strikes occurred in the first instance, or the bombs used in the second round failed to detonate, several aspects need to be examined.

First, the transformation in Indian attitude with regard to the use of military power to counter terrorism. Second, by actually crossing the LoC and carrying out a strike inside Pakistani territory, New Delhi upped the war ante, erroneously assuming that India alone controls the pace and direction of the conflict, and would also prevent war from escalating beyond the sub-conventional level. An inherently flawed assumption, as in a nuclear environment, there are no guarantees that the adversary may always respond with caution and restraint, and therefore escalation would not occur. India also misjudged Pakistan's peace signalling, restraint and non-provocation as a sign of the latter's weakness, and its air incursion on the second day, proved its entire calculations flawed. Third, India whether by carrying out these strikes (as in the case of Myanmar 2015 and Balakot 2019) or touting them effectively, without credible evidence (Azad Kashmir 2016), has used this strategy to maximise domestic benefits, as a part of its hybrid warfare stratagem. However, exploiting the enemy image to divert public attention from matters of critical concern may not always work effectively, and a sitting regime may lose its credibility if at any point this carefully crafted facade is challenged and exposed.

New Delhi is already facing criticism about this reckless action and nuclear brinksmanship. However, where the international community did

${ }^{56}$ Kasuri, Neither a Hawk nor a Dove, 434. 


\section{Salma Malik}

eventually use back channels to diffuse the crisis from hair trigger alert, and also has been vocal in mimicking India's narrative about IOJ\&K, there has been no effort at all to examine why and how a 22-year old Arts graduate was compelled to carry out this lone strike. An extremely tragic incident, but not the first of its kind, nor the last. Increasingly, all over the occupied Valley, the Kashmiri youth are either tortured and coerced by the Indian security forces to indulge in such acts, or traumatised by their plight, they are taking up arms. Once re-elected, Modi government fulfilled its agenda of revoking not only Article 370, but also 35-A of the Indian Constitution, that accorded special status to the occupied territories and ensured demographic sanctity of the Kashmiris. Fearing retaliation, the entire IOJ\&K has been under a lockdown as of August 5, 2019, with no access to basic necessities or link with the outside world. Even before the incident, New Delhi had linked Adil Dar to the JeM and also announced Jaish claiming responsibility, a well-crafted media strategy, which found an empathetic international audience. The fact that the JeM leadership in an audio recording ${ }^{57}$ denied any links or responsibility to the Pulwama attack was neither fully exploited by Pakistan, nor made known to the international community.

\section{'Surgical Strike' and Impact on Deterrence Stability}

One common assumption often made by strategic analysts is to consider the South Asian deterrence regime a mirror image of the Cold War model between the US and USSR spread over four-plus decades starting in the mid-1940s. By drawing a parallel, they dangerously err by generalising conclusions that could be disastrous in a crisis. Amongst the several factors that distinguish the South Asian model from that of US and USSR (Soviet Union), a few could be:

\footnotetext{
57 “JeM Chief Masood Azhar Denies Any Knowledge of Pulwama Attack in Latest Audio Message," Daily Pakistan, February 22, 2019, https://en.dailypakistan.com.pk/headline/jem-chief-masood-azhar-denies-anyknowledge-of-pulwama-attack-in-latest-audio-message/.
} 
- First and foremost the geographic proximity. Positioned next to each other, the reaction time between India and Pakistan in case of a crisis is critically low. Whereas, between the US and the Soviet Union, it was a minimum of 25 minutes. Sufficient enough for both the superpowers to initiate preventive measures; and possibly reverse a decision.

- India and Pakistan do not have the option to carry out their battles on proxy lands. During the Cold War, Europe primarily and the rest of the world prioritised strategic zones, and provided both the world powers ample space to avoid confrontation with each other.

- Afghanistan is being infiltrated by India to secure its interests as well as to protect what New Delhi has traditionally considered a part of its extended area of influence in accordance with the Indira and later Gujral doctrines. The complex interplay of state and non-state parties in Afghanistan, with each in pursuit of its interests, and a highly volatile border shared with Pakistan, and as a modern extension of Kautilya's Mandala theory - makes any conflict escalation as much problematic for Pakistan, as if it were taking place internally.

- The Cold War model represented fault lines marked by political ideologies and a feverish pursuit of power maximisation and influence. Whereas with regards to India and Pakistan, the seven-plus decades have not been able to help erase the trauma of partition, which finds a physical manifestation in the non-resolution of the Kashmir issue. A genuine humanitarian problem, which has now become a question of prestige, over which no negotiation seems possible.

- Realising the dangers of how close both the US and Soviet Union had brought the world to a nuclear holocaust, especially after the 1962 Cuban Missile Crisis, deliberate measures were mutually undertaken to diffuse and contain any chances of escalation. In the case of South Asia, Kargil, the Twin Peaks Crisis, various terrorist incidents and now the gimmickry of the surgical strike demonstrates an opposite tendency. Both the sides, willingly indulging in sub-conventional adventurism in 
Salma Malik

order to gauge the other's credibility and tolerance. A dangerous scenario, where these well-calculated measures, can at any time lead to inadvertent and uncontrollable crises.

- As the Cold War model, there have been a series of successful measures mutually agreed between India and Pakistan, on nuclear risk reduction and confidence building. The main framework was signed in 1999, to be followed up by high-level strategic contact groups. However, neither has there been any discussion on arms control or reduction nor has there been any improvement in the regime in the two decades since signing of the Lahore Declaration. As the peace process between the two neighbours eroded, correspondingly any progress made on strategic and nuclear issues also suffered a similar setback.

India is on a perpetual quest for power maximisation, through aggressive military purchases, and various military procurement deals as well as strategic agreements signed firstly with the US, and now the Russian Federation, as well as the $2+2$ Agreement signed in September 2018 on military and diplomatic front with the US, has created a major conventional as well as strategic imbalance in the region. These developments, further impact India's aggressive behaviour towards Pakistan, leaving no space for dialogue and peaceful engagement. Settlement of outstanding disputes or resolution of the festering Kashmir problem seems to be impossible, especially in the face of the defiant and antagonistic Doval Doctrine, which seeks the destruction of Pakistan. This has created such a belligerent mindset in India, that according to Tanham:

Indians consider the whole of the South Asian region as one political and strategic entity and that they intend to deny Pakistan the potential to challenge this claim. Most Indians strategists assume that Pakistan is the main hurdle in the Indian way for becoming the regional power in South Asia. ${ }^{58}$

${ }^{58}$ George K. Tanham. Indian Strategic Thought: An Interpretive Essay, report (Santa Monica, CA: Rand Corporation, 1992), 31. 
Indian Surgical Strike: Implications and Response by Pakistan

The growing conventional imbalance and the need to protect itself against India's belligerent posturing and designs were amongst the foremost reasons for Pakistan to seek the nuclear route. After overt nuclearisation, it was widely recognised by domestic actors that the two neighbouring rivals had achieved stability through effective nuclear deterrence and with sufficient examples of the dangers associated in tempering with this critical balance, both countries will act with caution and maturity. The 1999 nuclear risk reduction agreement, was appreciated both domestically as well as externally as a very positive step, which would strengthen the deterrence regime, and in the longer run, help in conflict mitigation. The architect of India's CSD and the man behind the 1986-87 Operation Brasstacks, General K. Sundarji had stated:

Nuclear deterrence would add stability and peace and that - the only salvation is for both countries to follow policies of cooperation and not confrontation...A mutual minimum nuclear deterrent will act as a stabilizing factor... The chances of conventional war between the two will be less likely than before. ${ }^{59}$

This belief in the strength of deterrence and recognition of the catastrophic dangers associated with the breakdown in deterrence was duly recognised and appreciated by both India and Pakistan. Despite many crises both the countries faced, there was always a conscious effort to maintain deterrence stability and exercise caution and escalation control.

The Kargil conflict was the first, where the limits of escalation control were tested. After Kargil, India remained in a constant struggle to re-engage with Pakistan. The only constricting factor was Pakistan's nuclear status, superimposed by a well-articulated nuclear command structure and declaration of nuclear red lines, without a deliberately

\footnotetext{
${ }^{59}$ William H. Lewis and Stuart E. Johnson, "Proliferation of WMD and the Security Dimensions in South Asia: An Indian View," in Weapons of Mass Destruction: New Perspectives on Counter Proliferation, eds. William H. Lewis and Stuart E. Johnson (Washington, D.C.: National Defense University Press, 1995), 59.
} 


\section{Salma Malik}

declared nuclear doctrine. Acknowledging the efficacy of Pakistan's strategy, Arka Biswas observed:

New Delhi's quest to explore space for conventional war below Pakistan's nuclear threshold - captured in the Indian Army's reference to devising the Cold Start doctrine of waging low-scale and sudden conventional attack in as early as 2004 - suggests that Pakistan did succeed in deterring possible Indian full-scale conventional attack. To further limit India's military options, Pakistan reduced its nuclear threshold by introducing tactical nuclear weapons, indicating its intent to use these low-yield, short-range nuclear weapons if India considers conducting a low-scale conventional attack. $^{60}$

However, the Indian lobby actively supporting sub-conventional military operations, such as the phantom surgical strike, promotes this dangerous development as reinforcing deterrence stability, rather than eroding it. Maintaining a similar view, Sumit Ganguly states that India 'has been grappling with an effort to forge a new military doctrine and strategy to enable it to respond to Pakistani needling, while containing the possibilities of conflict escalation, especially to the nuclear level. ${ }^{91}$ Thus, according to New Delhi, such sub-conventional strikes render the possibility of a collapse of nuclear deterrence negligible. Providing India with the option to retaliate, militarily, serves two purposes: appeases the domestic audience; and maintains the credibility of its mammoth sized conventional military. India is also aspiring to rebalance the status quo,

${ }^{60}$ Arka Biswas, "Surgical Strikes and Deterrence-Stability in South Asia" (paper, Observers Research Foundation, June 2017), 2, http://cf.orfonline.org/wpcontent/uploads/2017/06/ORF_OccasionalPaper_115_SurgicalStrikes_NEWFINAL.pdf

${ }^{61}$ Sumit Ganguly, "Nuclear Stability in South Asia," International Security 33, no. 2 (2008): 45-70. 
which had perceivably shifted in the adversary's favour, even if New Delhi cannot prevent similar sub-conventional strikes or attacks by Pakistan. ${ }^{62}$

This is an inherent dilemma of nuclear deterrence which is reflective in the classic stability/instability paradox. It states that where, on the one hand, nuclear weapons create stability at the macro level, they cannot prevent or deter instability at the micro level. With matching strategic capabilities, countries would never contemplate a full-fledged conventional war, but at the sub-conventional level, there could be many factors of kinetic and non-kinetic nature that could destabilise the deterrence regime. An aggressive campaign to undermine Pakistan's socioeconomic interests and pursuing a maligning campaign at the diplomatic level incrementally but steadily erodes deterrence stability and leaves little space for peaceful deliberations.

\section{Pakistan's Response and Implications}

One of India's major preoccupation, and more specifically of the Modi regime, has been to isolate Pakistan internationally and exploit the favourable global opinion to the maximum. At a time of acute global economic recession, India in its jubilant shopping spree seems to be getting a favourable nod from a majority of frontline powers, USA, the UK, Russia as well as Israel, are eager to oblige New Delhi's purchase of military hardware. For the US, a well-equipped India will be the most effective deterrent against China and also help the former in policing its interests in this vast region. For the others, it is hardcore market-driven competition. What the US, which still dominates the global security discourse, does not seem to realise is, that New Delhi has never been known to oblige or assist another country, unless its interests are being correspondingly fulfilled. Secondly, this strategic romancing is entirely at the cost of regional stability and order. The US naively assumes that empowering India will never be detrimental to its strategic interests, which is correct to a larger extent. However, the Kautilyan India, once empowered and strengthened, may end up surprising US' strategic calculations.

For Pakistan, which at present has been facing strong domestic as well as external security challenges, the need is for a delicate balancing act.

${ }^{62}$ Biswas, "Surgical Strikes and Deterrence-Stability in South Asia," 50. 


\section{Salma Malik}

For the interest and basic survival of the state, it is imperative not to allow any proxy actors to hijack or dominate the security discourse or the country's interests. It is equally essential for all institutions concerned to respond to challenges at home and abroad through a unified and unanimous face. Every institution, by its specific orientation, may have a different approach toward issues of national concern, but when it comes to overriding national interest through a consensus-based integrative approach, a mature state has to make the final decision. Pakistan's response to the McCain delegation in 2016, in post-Mumbai scenario was both unanimous and unambiguous that no compromise could be perceived over national sovereignty and survival.

Maintaining the same stance, in response to the provocative statements after the 2015 Myanmar strikes, Chaudhry Nisar Ali, thenInterior Minister of Pakistan stated:

Those having ill designs against Pakistan should listen carefully that our security forces are capable of matching a response to any adventurism... Indian leadership should stop daydreaming. ${ }^{63}$

Whereas, the Inter-Services Public Relations office remained watchful of India's hostile rhetoric, coupled with its covert and overt actions, to destabilise Pakistan. Responding to the statements by General Rawat and Prime Minister Modi, the military spokesperson, Major General Asif Ghafoor said that the country has a long-standing record of fighting terrorism and is ready for war, however, 'we know the price for peace. ${ }^{64}$

It is not that Pakistan lacks options to respond, however reacting to every provocation by New Delhi, would not only be a waste of time and energy but also provide them the needed excuse to engage Islamabad in a wasteful battle, draining the latter's resources and energy - in yet another manifestation of its complex hybrid war. Despite an understanding to

\footnotetext{
${ }^{63}$ Irfan Haider, "Pakistan is Not Myanmar, Will Respond to Foreign Aggression, Nisar Tells India," Dawn, June 10, 2015, https://www.dawn.com/news/1187363.

64 "We Are Ready for War, but Choose to Walk a Path of Peace: Pakistan Army," Dawn, September 22, 2018, https://www.dawn.com/news/1434329.
} 
ceasefire across the LoC, dating back to 2003, in the last 5-6 years, there has been an enormous loss of civilian lives, widescale casualties as well as destruction of infrastructure due to exchange of firing not only across the LoC, but also along the Working Boundary.

In May 2018, during a special hotline contact between the two Director Generals Military Operations (DGMO), both India and Pakistan agreed to restore the 2003 ceasefire agreement suggesting a new push to defuse years of tensions. ${ }^{65}$ This decision was not a sign of weakness, but an attempt to provide some relief and peace to the affected populations on both sides of the LoC. However, as with other agreements, it was also not honoured, creating further misery for the Kashmiri population.

New Delhi's aggressive posturing and its constant attempt to tarnish Pakistan's image, helps in diverting the focus of both domestic as well as international audience off its violations of human rights, atrocities against minority groups, especially Muslims and systematic killings of Kashmiri Muslims, in the name of counterterrorism.

Internally, the Indian security forces seem to be set on a kill-maim-blind-disable campaign in Kashmir.

Externally, New Delhi has embarked on a smear-isolatediscredit Pakistan mission. ${ }^{66}$

Building up such a significant threat scenario also provides India with the justification to increase its military budget and procurements. In the name of force modernisation, New Delhi's conventional weapons' shopping spree, is matched with its strategic ambitions, in which the US in order to counter China, is doing its best to turn India into a recognised NWS. Ironically, in this quest, not only is Washington blatantly selective, but willing to breach and reverse the various non-proliferation regimes and arrangements which it had pioneered or religiously adhered to.

${ }^{65}$ Kamran Yousaf, "Pakistan India Agree to Restore 2003 Ceasefire," Express Tribune, May 29, 2018, https://tribune.com.pk/story/1721920/1-hotline-contact-pakistan-indiadgmos-end-weeks-long-border-clashes/.

66 Imtiaz Gul, "Surgical Strikes and the Doval Doctrine," Friday Times, September 23, 2016, https://www.thefridaytimes.com/tft/surgical-strikes-and-the-doval-doctrine/. 


\section{Salma Malik}

How do all these developments affect Pakistan? Since its creation, Pakistan has faced existential threats emanating from its Eastern border. These threats have been strong enough to compel Islamabad seek external support for power balancing and also resulted in the dismemberment of the country. However, the country's leadership soon realised that unless there is an indigenous power potential, external help at best will remain interestoriented and conditional. This indigenous power balancer came in the shape of nuclear weapons' technology, which has served various purposes besides filling the military asymmetry as well as providing Pakistan with formidable deterrence. An ardent supporter of global disarmament regime, for Islamabad taking the nuclear path, became inevitable after its dismemberment and India entering the nuclear race first. Given the nonconductive and non-supportive political environment, for Pakistan, the path to overt nuclearisation was not at all an easy one, and unlike New Delhi, there was little cooperation available. Once nuclearised, the next challenge for Pakistan was to build a robust delivery and support system as well as setting up a doctrine.

With current threat perception, Pakistan has clearly stated that it would keep the option of Nuclear First Use (NFU) open. By developing a robust nuclear infrastructure, it has a wide range of weapon systems that allows Pakistan the flexibility of response, swift action, and Full Spectrum Deterrence (FSD). Although the country lacks a declared doctrine, which is deliberate for maintaining the element of surprise and ambiguity, red lines of exercising the nuclear option were informally provided as early as 2002 . In an interview with foreign correspondents, Lieutenant General Khalid Ahmed Kidwai, then-Director General of Strategic Plans Division had stated that nuclear weapons would be used only if the very existence of Pakistan is at stake. The four thresholds are:

1. India attacks and occupies a large part of the land, (space threshold).

2. India destroys a large part of the military forces (military threshold).

3. India creates political destabilization (domestic threshold).

4. India proceeds to economic strangulation (economic threshold). 
Kidwai's statement was reinforced by then-President Musharraf who in an interview to Der Speigel on April 5, 2002 stated:

Nuclear weapons would only be a last resort for us. We are negotiating responsibly, and I am optimistic and confident that we can defend ourselves using conventional weapons. ${ }^{67}$

India has always presented Pakistan's option of the First Use as an open declaration of war against it, and has, in this regard, exploited international sentiment to the maximum. However, even from a cursory read of the thresholds provided, it is amply clear that nuclear weapons option will be exercised only in the most extreme circumstances, and if unfortunately, the country faces an existential threat to its core assets spelled above as the last resort. Whereas India's much-publicised No First Use (NFU) option, has clearly been stated in the 1999 official text of India's declared nuclear doctrine 'against non-nuclear weapon states,' implying that NFU does not apply to nuclear-armed powers. Neither does it apply to chemical, biological or tactical nuclear weapons' attacks. ${ }^{68}$

Pakistan was content with maintaining a credible minimum deterrence, but India's CSD, and its provocative actions such as these strikes, compelled Islamabad to seek FSD, of which developing of shortrange, low yield nuclear weapons is a major cornerstone:

India has shifted the conflict to sub-conventional level by resorting to use of terrorism and proxies against Pakistan after realizing that conventional war is inconceivable due to its nuclear capabilities. The era of conventional hot wars is behind us. India can generate as much heat as it likes on Line of Control, including phantom 'surgical strike' from time to time, which in any case would be

\footnotetext{
${ }^{67}$ Menon, The Strategy Trap, 135.

${ }^{68}$ Rajesh Rajagopalan, “India’s Nuclear Doctrine Debate," (Washington: Carnegie Endowment for International Peace, 2016), https://carnegieendowment.org/2016/06/30/india-s-nuclear-doctrine-debate-pub-63950.
} 


\section{Salma Malik}

strongly retaliated by Pakistan and that is about it.... There are no aggressive overtones to our capability; the over-arching policy is Full Spectrum Deterrence but within the broader philosophy of Credible Minimum Deterrence. Pakistan will maintain peace and security in South Asia with an adequate level of armaments at all tiers: strategic, operational and tactical. ${ }^{69}$

This was stated by General Khalid Kidwai at a security workshop in December 2017, in response to India's increase in LoC aggression and Indian leaderships' public pronouncements against Pakistan. Furthermore, by staging the farce of a surgical strike, India is, firstly, dangerously and provocatively escalating the conflict ante, and secondly trying to bait Pakistan into possible nuclear usage, or else face a loss of credibility and image. As Karnad said, there is the Sialkot grab kind of option:

Keeping the city hostage as a bargaining chip that will prevent tactical nuclear first use by Pakistan for fear of vaporising its people and armed forces. Moreover, when the ceasefire is called, to use the captured city as a card to negotiate a final LoC-as-a-final border solution, the sort of victor's bargain Indira Gandhi could have legitimately imposed on Pakistan in 1971 but did not. ${ }^{70}$

By creating hype through media and carefully timed speeches and interventions at domestic and international fora, New Delhi created an ambience, a befitting narrative that would suitably justify its action and also win over the domestic audience. In characteristic Bollywood style, the brave and fearless soldiers invade, kill and return victorious without a scratch, leaving behind a massive enemy casualty count. But unfortunately, where its first surgical strike is still regarded phantom, the second resulted

\footnotetext{
69 "India has taken the Conflict to Sub-Conventional Level: NCA Adviser," Samaa Digital, December 6, 2017, https://www.samaa.tv/news/2017/12/india-taken-conflictsub-conventional-level-nca-adviser/.

${ }^{70}$ Karnad, Staggering Forward, 226.
} 
in two aircrafts downed; detention of one pilot in the hands of its adversary and the death of the second one. New Delhi erroneously assumed that like before, Pakistan will not retaliate, and only raise the issue at the diplomatic front, to broker peace, plus if so required, it would at best resort to theatre missiles as the primary line of defence. However, the response meted out was clear, a conventional strike would befittingly be met with a conventional retaliation, and that would be sufficient strategy for limited theatre engagement. In case of any escalation, whether spatial or force intensive, Pakistan's military would repulse, contain and respond accordingly. Provoking the adversary into nuclear usage or envisaging scenario such as the one given by Karnad above shows recklessness by Indian decision-makers, who are euphoric over the international attention being showered on them, without realising the consequences.

Since Mumbai, Indian strategic community has been contemplating revenge options ranging from a surgical strike on alleged militant camps in the heart of Punjab (as eluded by Kasuri), fuelling up Balochistan insurgency and also backchannel diplomatic and military engagement of the two sides. This entire anti-Pakistan diatribe, insatiable thirst for revenge and cutting the enemy to size is rooted is what the noted Indian columnist, A.G. Noorani referred to as the Dovalian Doctrine aimed at causing 'an obstinate Pakistan to kneel.' ${ }^{71} \mathrm{~A}$ brainchild of Indian National Security Advisor Ajit Doval, the NDA government's fixation with destroying Pakistan could not be more comprehensible.

\section{Conclusion}

Indian elections and the successive months have not only enhanced antiPakistan jingoism, but also created an atmosphere of acute fear and insecurity amongst the Muslims and minority groups in mainland India. The nearly nine month long curfew in Indian Occupied Jammu \& Kashmir and unilateral changes in the dispute, are a blatant violation of international norms and United Nations Security Council Resolutions over the issue.

In the absence of a viable conflict-resolution framework, and regional arms control mechanism, the Indian leadership's xenophobia, and deliberately constructed irrationality is fast eroding and deteriorating the

${ }^{71}$ Gul, "Surgical Strikes and the Doval Doctrine." 


\section{Salma Malik}

region's strategic stability. No longer faced with a security dilemma between India and Pakistan, but more likely what is referred as security quadrilemma ${ }^{72}$ involving the US and China as part of the larger equation, strategic competition and conflict is likely to enhance and become much more complicated. Pakistan needs to very prudently and logically make its strategic choices and decisions, based on rational calculations. With little hope for any concrete peace overtures, the need is to invest in the rapidly shrinking peace constituencies; address matters of critical concern which are affecting Pakistan's credibility and image worldwide; work hard to improve the country's economic profile; invest in sustainable effective governance; and lastly but most importantly, have a strong, visionary foreign policy.

72 Tahir Nazir, "Waning Nuclear Deterrence in South Asia," Bulletin of the Atomic Scientists, March 27, 2018, https://thebulletin.org/2018/03/waning-nuclear-deterrencein-south-asia/. 